\title{
A REDUÇÃO DA MAIORIDADE PENAL NUMA PERSPECTIVA CRIMINOLÓGICA: BOM PARA QUE(M)?
}

\section{AGE OF MAJORITY REDUCTION IN A CRIMINOLOGIC PERSPECTIVE: GOOD FOR WHOM?}

\author{
Aruani Kindermann Lapolli ${ }^{1}$ \\ Airto Chaves Junior ${ }^{2}$
}

\section{RESUMO}

A presente pesquisa tem por objeto o estudo da redução da maioridade penal como instrumento de contenção ao avanço da criminalidade juvenil. A pesquisa se justifica a medida em que a "bandeira da redução da maioridade penal" é levantada no plano social toda vez que repercute no meio midiático um ato infracional violento praticado por adolescentes. O seu objetivo geral é avaliar se a via penal é adequada e legítima para coibir comportamentos penalmente relevantes praticados por adolescentes. Os objetivos específicos são: a) estudar as funções do Direito Penal a partir das Teorias Funcionalistas; b) tratar da quebra paradigmática em criminologia que se revela desde a década de 1960; c) avaliar a função da pena sob a ótica da prevenção especial positiva, enraizada no plano legislativo brasileiro a partir daquilo que registra o art. $1^{\circ}$ da Lei de Execuções Penais; d) analisar se os objetivos de "proteção subsidiária e fragmentária de bens jurídicos" (Funcionalismo Moderado) e "reintegração social do apenado" (prevenção especial positiva) são efetivamente buscados e, por consequência, atingidos. Quanto à metodologia empregada, destacam-se duas fases distintas. A fase de investigação denota a utilização do método dedutivo, o qual foi subsidiado por pesquisa bibliográfica; nas considerações finais, trabalha-se com o método dialético, sobretudo porque o tema abordado não pode ser considerado fora de um contexto social.

Palavras-chave: Criminologia. Direito penal. Maioridade penal.

\begin{abstract}
This research aims to study the reduction of criminal majority as an instrument of containment to the advancement of youth crime. The research is justified to the extent that the "flag of lowering the criminal majority" has been raised in society, as reflected in the media, every time a violent offense is committed by teenagers. Its overall objective is to assess whether the criminal route is appropriate and legitimate to curb criminally relevant behavior practiced by teens. The specific objectives are: a) to study the functions of the criminal law from the Functionalist Theories; b) to talk about the paradigmatic break in criminology that reveals itself since the $1960 \mathrm{~s} ; \mathrm{c}$ ) evaluate the function of the sentence from the perspective of
\end{abstract}

\footnotetext{
1 Especialista em Direito Penal e Direito Processual Penal pela Escola Superior do Ministério Público do Estado de Santa Catarina. Especialista em Direito Processual Civil pela Universidade do Vale do Itajaí (UNIVALI). Servidora Pública do Poder Judiciário do Estado de Santa Catarina. E-mail: aruani@tjsc.jus.br. 2 Doutorando e Mestre em Ciência Jurídica pela Universidade do Vale do Itajaí (UNIVALI). Professor Titular de Direito Processual Penal e Direito Penal pela mesma universidade. Professor da Escola do Ministério Público do Estado de Santa Catarina. Advogado Criminalista em Santa Catarina. E-mail: oduno@ hotmail.com.
} 
positive special prevention, rooted in Brazilian law from what records the art. 1 of the Law of Penal Execution; d) analyze whether the goals of "subsidiary and fragmentary protection of legal goods" (Functionalism Moderate) and "social reintegration of the convict" (positive special prevention) are effectively pursued and consequently achieved. Regarding methodology, we highlight two distinct phases. The research phase denotes the use of the deductive method, subsidized by bibliographical research; the final considerations were build upon with the dialectical method, mainly because the issue addressed can not be considered outside of a social context.

Keywords: criminology; criminal Law; legal majority.

\section{Introdução}

A pesquisa que aqui se inicia tratará do Direito Penal como instrumento (i)legítimo para contenção da criminalidade juvenil, e o tema a ser abordado em sua centralidade será o da redução da maioridade penal.

Por disposição constitucional, no Brasil, um cidadão só passa à imputabilidade depois de completados 18 anos. Assim, os menores de 18 anos são inimputáveis, sendo essa presunção absoluta, pois o critério aqui adotado é puramente biológico, de maneira que nenhuma outra circunstância de natureza psicológica altera a idade penal. A maior especulação em torno do tema é a (im)possibilidade de redução de 18 para 16 anos.

O tema "redução da maioridade penal" ressurge quando se tem um injusto de grande repercussão nacional envolvendo, no polo ativo da infração, crianças ou adolescentes. A partir disso, a mídia clama por penas exemplares, encarceramentos e instrumentos que aparecem camuflados no perigoso discurso: "algo precisa ser feito". Em miúdos, precisa-se de mais Direito Penal.

Sem adentrar aqui no plano midiático e na influência que os telejornais podem exercer sobre a opinião pública (pois, inegavelmente, um crime é tanto mais grave quanto mais atenção um programa "policialesco" de boa audiência dispensa sobre o caso), enraíza-se um macabro consenso por meio de um intenso bombardeio de justificativas, todas elas extremamente propensas a se utilizar do sistema repressivo em um instrumento político promocional de bem estar social. A primeira dúvida que surge neste contexto é a seguinte: "bem estar de quem?".
Acredita-se, em um primeiro plano, que os problemas da criminalidade e da segurança pública serão resolvidos com o encarceramento de alguém. Tanto isso ocorre que, em pesquisa do Datafolha ${ }^{3}$ divulgada em abril de 2013, constatou-se que 93\% dos moradores da capital do estado de São Paulo concordam com a diminuição da idade em que uma pessoa deve responder criminalmente por seus atos. A mesma pesquisa revelou que apenas $6 \%$ dos entrevistados eram contra a redução. Em consultas anteriores, em 2003 e 2006, a aprovação à medida pelos moradores da cidade foi de $83 \%$ e $88 \%$, respectivamente.

A nível nacional, a pesquisa da $\mathrm{CNT}^{4}$ (Confederação Nacional do Transporte), feita em parceria com o instituto MDA, divulgada em junho de 2013, revelou que a redução da maioridade penal de 18 para 16 anos é aprovada por $92,7 \%$ dos brasileiros.

A peça publicitária sustentadora da redução da maioridade penal - muito bem desenhada, por sinal - constitui-se em algumas premissas bastante divulgadas e incorporadas ao discurso: a) é cada vez maior o número de menores envolvidos em práticas criminosas; b) o Estatuto da Criança e Adolescente não é eficaz, porque as respostas ("medidas socioeducativas") nele previstas são muito brandas; c) os autores intelectuais dos crimes (maiores) se utilizam dos menores para sua prática; e d) para reduzir essa violência promovida pelo público juvenil, o Direito Penal é a saída mais rápida e eficaz.

\footnotetext{
3 BENITES, Afonso. Folha de São Paulo. 93\% dos paulistanos querem redução da maioridade penal. Matéria veiculada em 17/04/2013.

4 DOURADO, Kamilla. Portal R7 Notícias. Mais de $90 \%$ da população aprova a redução da maioridade penal. Matéria veiculada em 11/6/2013.
} 
Essas premissas, verdadeiras ou não, revelam uma situação de fato fundamentada em um sentimento quase que comum: a necessidade de adoção de medidas penais urgentes, já que outras vias de solução que o Estado dispunha não seriam capazes de produzir o mesmo efeito dissuasivo.

A questão é: o Direito Penal é o instrumento adequado para resolver esse tipo de questões?

Inicialmente, deve-se evitar o raciocínio simplista de que do Direito Penal se extraem resultados positivos e em conformidade com o proposto. Não se pode ignorar que o Sistema Penal em que o Direito está inserido produz efeitos altamente prejudiciais aos seus alvos (diretamente) e a todo corpo social (por via indireta e secundária), pelo que, somente se justificaria em situações realmente excepcionais. Além disso, nessas condições de excepcionalidade, não se pode deixar, ainda, de buscar coerência a este Sistema Penal, o que significa articular de forma construtiva os antagonismos que o corpo social revela.

A (des)legitimidade do Direito Penal para solução dessa espécie de problema é ancorada em diversos pilares, das quais duas ganharão relevância na pesquisa que aqui se desenvolve: a) o Direito Penal como instrumento legítimo de proteção de bens jurídicos essenciais à coexistência (Princípio da Exclusiva Proteção dos Bens Jurídicos) e, uma vez violado, o bem jurídico penalmente tutelado; e b) a reintegração do apenado por meio da pena privativa de liberdade (prevenção especial positiva).

Toda a sociedade revela um interesse premente na redução da criminalidade infanto-juvenil. Porém, é importante a utilização de instrumentos e meios idôneos e legítimos e não de embustes que só tendem a mascarar os problemas e, talvez, potencializar os danos deles decorrentes.

Seria o Direito Penal um instrumento solucionador? Ou, então, meio potencializador desses problemas? É o que se pretende avaliar na sequência.

\section{AS FUNÇÕES DO DIREITO PENAL}

Os estudos das concepções instrumentais do Direito Penal são fundamentais para a compreensão da (in)viabilidade da redução da maioridade penal, pois é no Sistema Penal que se pretende incluir o menor infrator a partir do descimento do fator cronológico de imputabilidade penal (de dezoito para dezesseis anos).

Entende-se por funcionalismo penal a concepção metodológica segundo a qual os conceitos e o sistema do Direito Penal devem ser construídos com base em considerações normativas, referentes aos fins do Direito Penal e a seus pressupostos de legitimidade. ${ }^{5}$

Essa concepção funcional ganhou força a partir da década de 1970 com o escrito sobre Política Criminal e Sistema Jurídico Penal de autoria do penalista alemão Claus Roxin. ${ }^{6}$ Desde então, a ideia de um Direito Penal instrumental e de protetor do "bem jurídico" é bastante difundida, sobretudo, após a sedimentação dos critérios de subsidiariedade e fragmentariedade tratados pelo jurista, que reunidos, buscam uma intervenção penal minimalista. Tratase de uma das facetas do funcionalismo penal: ${ }^{7} \mathrm{o}$ Direito Penal como função tutelar, protetora de bens jurídicos.

Conforme Roxin, ${ }^{8}$ o Direito Penal deve garantir os pressupostos de uma convivência pacífica, livre e igualitária entre os homens, na medida em que isso não seja possível por meio de outras medidas de controle sócio-políticas menos gravosas. Essa finalidade estaria condicionada a um pressuposto limitador: a pena só pode ser cominada quando for impossível obter esse fim mediante outras medidas

\footnotetext{
5 GRECO, Luiz Felipe. Funcionalismo Penal. Dicionário de Filosofia do Direito. Vicente de Paulo Barreto (Coord.). São Leopoldo/RS: Editora Unisinos; Rio de Janeiro: Editora Renovar. 2006, p. 369.

6 ROXIN, Claus. Política criminal e sistema jurídico-penal. Tradução de Luís Greco. Rio de Janeiro: Renovar, 2002.

7 Neste caso, refere-se ao Funcionalismo moderado, teleológico ou valorativo. O outro aspecto é chamado de Funcionalismo radical, estratégico normativo, construído pelo também penalista alemão Güinther Jakobs a partir do funcionalismo sistêmico do sociólogo Niklas Luhmann. É "sistêmico" porque a preocupação dele não é com o bem jurídico, mas com o sistema. Assim, para Jakobs, a finalidade primeira do Direito Penal é a reafirmação da autoridade da norma. Neste caso, a função do direito penal é proteger e resguardar o sistema. Conforme Muñoz Conde, Günther Jakobs propõe um modelo de dogmática jurídico-penal compatível tanto com um Estado Social e Democrático de Direito como também, com um Estado Nacional Socialista Alemão, ou ainda, com qualquer outro modelo de Estado que nega os Direitos Humanos. MUÑOZ CONDE, Francisco. Edmund Mezger e o Direito Penal de seu tempo: estudos sobre o Direito Penal no nacional-socialismo. 4. ed. Tradução de Paulo César Busato. Rio de Janeiro: Lumen Juris, 2005, p. 66-68.

8 ROXIN, Claus. Estudos de Direito Penal. 2. ed. Tradução de Luís Greco. Rio de Janeiro: Renovar, 2008, p. 32-33.
} 
menos gravosas, de maneira que o Direito Penal seria desnecessário quando se poderia garantir a proteção desses bens pelo Direito Civil, por proibições administrativas ou por medidas preventivas judiciais.

Essa teoria do bem jurídico ${ }^{9}$ se refere ao funcionalismo moderado, teleológico ou valorativo. A ideia de valor está bastante presente na construção funcionalista desenvolvida por Roxin, de maneira que cada conceito (conduta, tipicidade, ilicitude e culpabilidade) deve ser avaliado sob um prisma Político Criminal, ou seja, analisado sob uma orientação voltada aos direitos fundamentais e os valores do Estado Social e Democrático de Direito.

Não se recorre, então, a categorias ontológicas do ser. Leva-se em conta, por outro lado, o aspecto normativo, o fundamento, a função que cada conceito tem de cumprir no sistema da Teoria do Delito, especialmente no que se refere ao injusto penal, com a chamada teoria da imputação objetiva. Conforme essa teoria, o injusto não é apenas um acontecimento causal (causalismo), nem tampouco final (finalismo), mas, primariamente, a realização de um risco não permitido criado pelo autor da conduta. Assim, o núcleo do injusto penal se desloca de um dado ôntico de caráter físico (causalismo) ou psicológico (finalidade) para se firmar num ponto de vista normativo, que seria o risco juridicamente desaprovado, criado e realizado. Assim, para a teoria da imputação objetiva, ainda que presentes os dois citados dados ônticos, caso o comportamento do sujeito não tenha criado um risco proibido, está-se diante de um indiferente penal. ${ }^{10}$

Neste contexto, Roxin ${ }^{11}$ explica que o ato de vender um punhal a uma pessoa de aparência suspeita, apesar de criar certo risco, não pode ser

9 Acerca da expressão "bem jurídico", são importantes os registros de Luís Greco: "No Brasil, a doutrina tradicional, a rigor, nem sempre utiliza as palavras 'bem jurídico', preferindo por vezes o termo objeto ou objetividade jurídica. Como esta diferença é apenas terminológica, pode-se dizer que ela já conhecia o conceito de bem jurídico, mas em sua dimensão exclusivamente dogmática. Ou seja, a nossa doutrina, acostumada exclusivamente com o conceito dogmático de bem jurídico, não costuma reconhecer qualquer função crítica ou política-criminal à ideia. Em geral, só a partir de investigações mais recentes se começou a propor um conceito de bem jurídico como diretriz para o legislador". In: "Princípio da ofensividade" e crimes de perigo abstrato - Uma introdução ao debate sobre o bem jurídico e as estruturas do delito. Revista Brasileira de Ciências Criminais. Biblioteca Cláudio Guimarães. Obra ${ }^{\circ}$ 960. Julho - agosto de 2004. Ano 12, p. 93-94.

10 GRECO, Luiz Felipe. "Funcionalismo Penal". Dicionário de Filosofia do Direito, 2006, p. 369.

11 ROXIN, Claus. Estudos de Direito Penal, 2008, p. 105. considerado risco proibido, pois uma vida ordenada em sociedade só é possível se o indivíduo, em princípio, puder confiar que as pessoas com quem interage não cometerão crimes dolosos. Do contrário, além dos punhais, igualmente não poderiam ser vendidos ou emprestados materiais inflamáveis, fósforos, machados, enxadas, etc.

E, sendo o Direito Penal instrumento de proteção dos bens jurídicos mais importantes, como é feita essa proteção pelo Estado? O Estado tipifica comportamentos e impõe sanções àqueles que violarem as regras (tipicidade e pena). Aliás, Rogério Greco $^{12}$ bem lembra que a censura vem corporificada por meio da pena. É ela que irá ditar a gravidade do mal praticado.

Assim, o primeiro limite imposto ao direito de punir do Estado é a mais estrita necessidade de recorrer à punição (pena ou medida de segurança), consubstanciado em dois princípios fundamentais: a) o da subsidiariedade na seleção dos bens jurídicos (que opera in abstrato); e b) a proteção de bens jurídicos deve suportar forma fragmentária, limitada a ataques mais perigosos (que ocorre in concreto). Conforme Santiago Mir Puig, ${ }^{13}$ negligenciar esses critérios seria abandonar algumas das tarefas sócio-políticas das quais o Estado se propõe a cuidar.

A utilidade principal que cobre o estudo desse limite do poder punitivo do Estado é que ele deriva, especialmente, de uma operação funcional, de condições de justificação da punição e a sua necessidade de proteger a sociedade. O fundamento político (que anuncia uma abordagem impositiva de respeito ao Estado Democrático de Direito) ficaria num segundo plano.

Resumidamente, conforme os adeptos do funcionalismo moderado, o Direito Penal é um dos instrumentos de proteção dos bens jurídicos e, neste caso, de proteção àqueles bens de maior relevância ao convívio social. Mas, uma dúvida aqui é levantada: quais os critérios de seleção desses bens jurídicos para tutela penal? Como chegar ao quantum para determinar que um comportamento é mais grave que o outro e, consequentemente, deve comportar pena maior?

12 GRECO, Rogério. Direito Penal do Equilíbrio: uma visão minimalista do Direito Penal. 4. ed. Niterói: Impetus, 2009, p. 65.

13 MIR PUIG, Santiago. Introducción las bases Del Derecho Penal. Montevideo: Julio César Faira Editor, 2003, p. 112. 
A seleção dos bens jurídicos varia de sociedade para sociedade. Assim, o critério de seleção será o valorativo-cultural, conforme a necessidade de cada época. Existe uma zona de consenso, comum a toda e qualquer sociedade, no sentido de proteção a determinados bens, com a criação de certas figuras típicas, como ocorre, por exemplo, com as condutas que encontram tipicidade nos crimes de roubo e homicídio. Por outro lado, existem zonas de conflito, nas quais condutas que são incriminadas em determinadas sociedades já não o são em outras, a exemplo do aborto. ${ }^{14}$

De qualquer forma, a coerção penal (basicamente, a pena) deve procurar materializar uma aspiração ética que será a razão de atuação do próprio Direito Penal (seu "por que" e seu "para que") a fim de buscar a prevenção de futuras afetações de bens jurídicos. Essa concepção funcional prevalece no âmbito doutrinário como verdadeira missão do Direito Penal, embora não exista consenso quanto ao conteúdo dessa proteção. Tanto que Hassemer ${ }^{15}$ afirma que a proibição penal de comportamentos desvinculados da tutela de bens jurídicos realmente essenciais não é outra coisa senão um terror estatal.

Então, para compreensão da presente pesquisa, se faz necessário entender a prevalência do discurso no sentido de Direito Penal como instrumento protetor de bens jurídicos, ${ }^{16}$ isso para que se perfaça um "corte" dessa concepção instrumental para a função selecionadora de pessoas, pois, num plano manifesto, o Estado se utiliza do Direito Penal se voltando quase sempre contra certas pessoas, raramente contra certas condutas. Tanto que uma parcela de privilegiados possui a capacidade de impor ao sistema uma quase total impunidade das próprias condutas criminosas. ${ }^{17}$

\footnotetext{
14 GRECO, Rogério. Direito Penal do Equilíbrio, 2009, p. 67.

15 WINFRIED, Hassemer. Darf es Strafteten geben, die ein strafrechtliches Rechtsgut nicht in Mitleidenschaft ziehen? In: die Rechtsgutstheorie. Legitimationsbasis des Strafrechts oder dogmatisches Glasperlenspiel?, org. Por Hefendehl, v. Hirsch e Wohlers, Baden-Baden: Nomos, 2003, p. 64.

16 PRADO, Luiz Regis. Curso de Direito Penal Brasileiro: parte geral. V. 1. 5. ed. São Paulo: Editora Revista dos Tribunais, 2005, p. 53.

17 CHAVES JUNIOR, Airto; MENDES, Marisa Schmitt Siqueira. "A miséria atrás das grades: a produção da criminalidade a partir da seletividade da norma penal". Revista Direito e Justiça - Reflexões Socio jurídicas - Ano IX - No 12- Março 2009, p. 14.
}

\subsection{Seleção de bens ou seleção de pessoas? Notas sobre o Funcionalismo Contencionista}

A concepção funcional contencionista é teorizada por Eugênio Raúl Zaffaroni ${ }^{18}$ desde a década de 1980. Conforme esse autor, a função do Direito Penal de todo Estado de Direito (da doutrina penal como programadora de um exercício racional do poder jurídico) deve ser a redução e a contenção do poder punitivo dentro dos limites menos irracionais possíveis.

Neste caso, se o Direito Penal não consegue que o poder jurídico assuma esta função, lamentavelmente terá fracassado, pois é ele um apêndice indispensável do Direito Constitucional do Estado de Direito, o qual se encontra sempre em tensão dialética com o chamado "Estado de polícia". Diante dessa perspectiva, a função do Direito Penal, como instrumento do Estado de Direito, seria reduzir a violência do Estado de polícia, bem como, a seletividade que lhe é intrínseca.

Paulo Cesar Busato ${ }^{19}$ lembra que esta concepção é ancorada numa Criminologia Crítica, que preconiza que o Direito Penal possui o objetivo declarado pelo discurso jurídico oficial de proteção de bens jurídicos essenciais (Funcionalismo Moderado), mas, por outro lado, comporta objetivos reais ou latentes, ocultados pelo discurso jurídico oficial e proclamados pelo discurso jurídico crítico.

A seletividade de pessoas, notadamente aquelas mais vulneráveis do ponto de vista econômico é característica marcante do sistema. Isso acaba por colocar o Direito Penal como instrumento contendor de comportamentos praticáveis por grupos determinados, de forma que criminaliza certos padrões de conduta e imuniza outros comportamentos que, num plano material, são tão ou mais reprováveis que aqueles em que o Direito Penal realmente ataca. Neste sentido, Juarez Cirino dos Santos ${ }^{20}$ anota que crime é o que a lei, ou a justiça criminal, determina como

\footnotetext{
18 ZAFFARONI, Eugenio Raúl. O inimigo no direito penal. Tradução de Sérgio Lamarão. Rio de Janeiro: Revan, 2007, 3. ed. 2007.

19 BUSATO, Paulo César; BASSO, Stephan Nascimento. "Funções e Missões do Direito Penal”. In: BUSATO, Paulo César (Org.). Fundamentos de Direito Penal (Direito Penal baseado em casos). Curitiba: Juruá Editora, 2013, p. 29.

20 SANTOS, Juarez Cirino. A criminologia radical. 2. Ed. Curitiba: ICPC; Lumen Juris, 2006, p. 9.
} 
crime, excluindo comportamentos não definidos legalmente como crimes, por mais danosos que sejam, tais como o imperialismo e a exploração do trabalho; ou comportamentos que, apesar de definidos como crimes, não são processados nem reprimidos como crimes, como a criminalidade de "colarinho branco".

Zaffaroni $^{21}$ demonstra o critério seletivo do Direito Penal como forma de contenção da criminalidade. É que, historicamente, o poder punitivo sempre discriminou certos grupos de seres humanos e lhes conferiu um tratamento punitivo sem correspondência à condição de pessoas.

Desde a era pré-moderna, o poder punitivo conferiu um tratamento punitivo que não correspondia à condição de pessoas a grupos mais vulneráveis e mais distantes aos centros de poder. Esses seres humanos são assinalados como inimigos da sociedade e, por conseguinte, o controle constante deve recair sobre eles.

Assim, desde sua própria origem, o poder punitivo mostrou uma formidável capacidade de perversão, montada - como sempre - sobre um preconceito que impõe medo, sempre admitido e ratificado abertamente pelos teóricos de seu tempo. ${ }^{22}$

No século XV, o livro Malleus Maleficarum, também chamado $O$ martelo das feiticeiras ${ }^{23}$ foi escrito pelos inquisidores alemães Heinrich Kramer e James Sprenger a pedido do Papa Inocêncio VIII. O objetivo era enfrentar as conspirações demoníacas contra a Cristandade, praticada pelo inimigo da Igreja Católica, a mulher. Essa obra foi publicada pela primeira vez em 1486 e até o final do século XVIII foi o fundamento jurídico e teológico dos tribunais da Inquisição em diversos países.

Os autores afirmavam que as bruxas representavam as mulheres em estado natural. A obra foi considerada um verdadeiro Tratado de Criminologia que enviou milhares de mulheres às fogueiras da Inquisição. Aconselhava que todas as suspeitas de bruxaria fossem submetidas à tortura: se confessassem mereceriam o fogo; se não confessassem, também, pois só uma bruxa, fortalecida por influência do

\footnotetext{
21 ZAFFARONI, Eugenio Raúl. O inimigo no direito penal, 2007, p.11.

22 ZAFFARONI, Eugenio Raúl. O inimigo no direito penal, 2007, p. 34

23 KRAMER, Heinrich; SPRENGER, James. O martelo das feiticeiras. Rio de Janeiro: Rosa os Tempos, 1997.
}

Demônio poderia resistir à semelhante suplício sem ceder à confissão. ${ }^{24}$

Fora da Europa, o poder colonialista legitimado por estes discursos exerceu-se sob a forma de genocídio. Os índios ignoravam os dez mandamentos, os sete sacramentos e os sete pecados capitais; não conheciam a palavra pecado nem temiam o inferno; não sabiam ler nem tinham nunca ouvido falar em direito de propriedade. ${ }^{25}$ Essas características demarcavam a inferioridade dos índios e sua duvidosa humanidade, o que justificaria qualquer brutalidade contra eles.

Dessa forma, a conquista da América foi uma longa e difícil tarefa de exorcismo, eliminando a maior parte da população americana da época, desbaratando suas organizações sociais e políticas e reduzindo essas pessoas à condição de servidão e escravidão. ${ }^{26}$

A exigência da mão de obra extrativa determinou o tráfico escravista africano, levado a cabo pelos comerciantes ingleses, franceses e holandeses, que compravam prisioneiros de toda costa da África, provocando, desse modo, a destruição das culturas pré-coloniais dos dois continente. ${ }^{27}$ Durante os séculos XVI, XVII e XVIII, este intercâmbio foi caracterizado pela troca de escravos por fuzis. Depois, durante os séculos XIX e XX, a África entregou ouro, diamantes, cobre, marfim, borracha e café, recebendo em troca Bíblias. Trocou produtos por palavras, supondo-se que a leitura da Bíblia podia facilitar a viagem dos africanos do inferno para o paraíso. Porém, a Europa se esqueceu de ensiná-los a ler. ${ }^{28}$

Finalmente, na América Latina, o estereótipo do desviante sempre se alimenta das características de homens jovens das classes mais carentes, ${ }^{29}$ ou

24 Conforme registra Eduardo Galeano oito séculos mais tarde, a Igreja Católica continua negando o púlpito às mulheres. Mesmo assim, o mesmo pânico faz com que os mulçumanos fundamentalistas as mutilem o sexo e lhes cubram o rosto. E o alívio pelo perigo conjurado leva os judeus mais ortodoxos a começar o dia sussurrando: Graças, Senhor, por não me ter feito mulher (In: GALEANO, Eduardo. Espelhos: uma história quase universal. Tradução de Eric Nepomuceno. 2. ed. Porto Alegre: L\&PM, 2009, p. 115-116).

25 GALEANO, Eduardo. Espelhos: uma história quase universal. Tradução de Eric Nepomuceno. 2. ed. Porto Alegre: L\&PM, 2009, p. 118.

26 ZAFFARONI, Eugenio Raúl. O inimigo no direito penal, 2007, p. 34-35.

27 ZAFFARONI, Eugenio Raúl. O inimigo no direito penal, 2007, p. 35.

28 GALEANO, Eduardo. Os demônios do demônio. Disponível em <http:// titaferreira.multiply.com/reviews/item/143> Acesso 12 nov. 2009.

29 A exceção ocorre nos momentos de violência política ou terrorismo de estado escancarado, nos quais o estereótipo se desvia para varões jovens das 
seja, pessoas que, por alguma razão, não respondem às normas vigentes e não estão afetas aos processos de controle preventivo.

Zaffaroni ${ }^{30}$ adverte que o sistema penal não se trata simplesmente de um acordo externo, mas também de sério "tratamento" integrado em um complexo processo de deteriorização, cuja parte mais importante é feita pela prisão e perfeitamente legalizado mediante registros de reincidência, da possibilidade de impedir ou dificultar qualquer exercício de trabalho honesto por parte das agências do sistema. A preocupação, neste caso, é propagar o status do criminalizado, de privar de liberdade periodicamente a pessoa, ${ }^{31}$ convertendo-a em um "suspeito profissional", de tomar os antecedentes como provas de culpa, inclusive por parte dos juízes, ${ }^{32}$ etc.

Observa-se que os agentes do controle social desfrutam de ampla margem de discricionariedade na seleção que realizam. Nada mais errôneo que supor (como sustenta a Dogmática Penal) que, detectando um comportamento delitivo, seu autor resultará automática e inevitavelmente etiquetado. Entre a seleção abstrata, potencial e provisória operada pela lei penal e a seleção efetiva e definitiva operada pelas instâncias de criminalização secundária, medeia um complexo e dinâmico processo de refração. ${ }^{33}$

\footnotetext{
classes médias (o "jovem subversivo", ao qual se contrapõe o "jovem esportista"). ZAFFARONI, Eugenio Raúl. Em busca das penas perdidas: a perda da legitimidade do sistema penal. 5. ed. Tradução de Vânia Romano Pedrosa e Amir Lopez da Conceição. Rio de Janeiro: Revan, 2012, p. 131.

30 ZAFFARONI, Eugenio Raúl. Em busca das penas perdidas: a perda da legitimidade do sistema penal. 5. ed. Tradução de Vânia Romano Pedrosa e Amir Lopez da Conceição. Rio de Janeiro: Revan, 2012, p. 134-135.

31 Sabe-se que, mais genericamente, as práticas judiciárias aparentemente mais neutras e mais rotineiras, a começar pela aplicação da pena provisória, tendem sistematicamente a desfavorecer as pessoas de origem mais humilde e fragilizadas do ponto de vista econômico.

32 "Os juízes são os empregados que quase não se rebelam desse mecanismo. Ajudam na medida de suas possibilidades a constituição da delinquência, ou seja, a diferenciação das ilegalidades, o controle, a colonização e a utilização de algumas delas pela ilegalidade da classe dominante" (In: FOUCAULT, Michel. Vigiar e Punir: história de violência nas prisões. Petrópolis/RJ. Ed. Vozes, 1989, p. 248); O juiz irá, no Processo Penal, coordenar os diversos saberes para formatar o indivíduo ao padrão normal, assumindo feição disciplinar repressora (In: MORAIS DA ROSA, Alexandre. Decisão Penal: a bricolage de significantes. Rio de Janeiro: Lúmen Juris, 2006, p. 210). 33 "Refração", porque, dependendo da situação e do caso colocado sob apreciação das agências de repressão, a solução pode ser das mais surpreendentes. Para exemplificar, Eduardo Galeano lembra que, em 1997, um chefe indígena brasileiro chamado Galdino de Jesus dos Santos que estava de visita em Brasília, foi queimado vivo enquanto dormia em uma parada de ônibus. Cinco rapazes de boas famílias, que andavam farreando, jogaram álcool e lhe tocaram fogo. Pensamos que era um mendigo, justificaram eles. Um ano depois, a justiça brasileira lhes aplicou penas alternativas, pois não se tratava
}

Desde os trabalhos pioneiros de Georg Rusche e Otto Kirchheimer, ${ }^{34}$ confirmados por cerca de 40 estudos empíricos em uma dezena de sociedades capitalistas, ${ }^{35}$ sabe-se que existe no nível societário uma estreita e positiva correlação entre a deterioração do mercado de trabalho e o aumento da população carcerária, ao passo que não existe vínculo algum comprovado entre índice de criminalidade $\mathrm{e}$ índice de encarceramento.

Vera Malagutti Batista, ${ }^{36}$ ao pesquisar processos do Juizado da Infância e Juventude do Rio de Janeiro, e neles a posição dos juízes, promotores, psiquiatras, psicólogos e assistentes sociais, concluiu que "todos os lapsos, metáforas, metonímias, todas as representações da juventude pobre, como suja, imoral, vadia, perigosa, formam o sistema de controle social no Brasil de hoje e informam o imaginário social para as explicações da questão da violência urbana. E talvez por isso, um dos inimigos do Estado hoje seja, efetivamente, aquele grupo de adolescentes mais vulnerável ao alcance dos direitos que esse mesmo Estado declara proporcionar de forma certa igualitária".

Por isso, Zaffaroni ${ }^{37}$ defende um funcionalismo redutor como única maneira de legitimar o poder punitivo seletivo como é o que se tem. Para tanto, é importante rever o que foi registrado por Michel Foucault $^{38}$ que anota ser necessário abandonar a ilusão de que a penalidade é, antes de tudo, uma maneira de reprimir os delitos; estudar os sistemas punitivos concretos como fenômenos sociais que não podem ser explicados pela armadura jurídica da sociedade nem por suas opções éticas primordiais, mas recolocá-los em seu campo de funcionamento

\footnotetext{
de um caso de homicídio qualificado. O relator do Tribunal de Justiça do Distrito Federal explicou que os rapazes tinham utilizado apenas a metade do combustível que possuíam e isto provava que tinham atuado movidos pelo ânimo de brincar, não de matar. In: $\mathrm{O}$ crime que abalou o Brasil e o mundo: o assassínio do índio Pataxó Galdino Jesus dos Santos, queimado vivo por brincadeira. Disponível em <http://members.tripod.com/arlindo_ correia/101201.html> 10 out. 2008.

34 Ver RUSCHE, Georg; KIRCHHEIMER, Otto. Punição e estrutura social. Tradução de Gizlene Neder. Rio de Janeiro: Freitas Bastos/Instituto Carioca de Criminologia, 1999.

35 WACQUANT, Loïc. As prisões da miséria. Tradução de André Telles. Rio de Janeiro: Jorge Zahar Editor, 2001.

36 BATISTA, Vera Malaguti. Difíceis ganhos fáceis: drogas e juventude pobre no Rio de Janeiro. Rio de Janeiro: Revan, 2003, p 120.

37 ZAFFARONI, Eugenio Raúl. O inimigo no direito penal, 2007, p. 88.

38 FOUCAULT, Michel. Vigiar e punir: nascimento da prisão. 39 ed. Rio de Janeiro: Editora Vozes, 2011, p. 27/28.
} 
em que a sanção não é o único elemento, podendo-se dizer que a definição das infrações e suas repressões são feitas em compensação para manter os mecanismos punitivos e suas funções.

Assim, conforme a concepção contencionista, a função do Direito Penal de todo Estado de Direito deve ser a redução e a contenção do poder punitivo dentro dos limites menos irracionais possíveis, de maneira que se o Direito Penal não consegue que o poder jurídico assuma esta função, terá lamentavelmente fracassado, perecendo o Estado de Direito e, por via de consequência, avançado o Estado de polícia. ${ }^{39}$

Friedrich Nietzsche, ${ }^{40}$ póstumo do seu tempo, já ambicionava a redução, senão, o desaparecimento do Direito Penal:

(...) Vocês, homens prestativos e bem-intencionados, ajudem na obra de erradicar do mundo o conceito de punição, que o infestou inteiramente! Não há erva mais daninha! Ele não apenas foi introduzido nas consequências de nossas formas de agir - e como já é terrível e irracional entender causa e efeito como causa de punição! -, mas fezse mais, privando da inocência, com essa infame arte interpretativa do conceito de punição, toda a pura casualidade do acontecer. A insensatez chegou ao ponto de fazer sentir a existência mesma como punição - é como se a educação do gênero humano tivesse sido orientada, até agora, pelas fantasias de carcereiros e carrascos!

Considerando-se que o paradigma reducionista tem por base a teoria criminológica da reação social, tratada adiante, vale ressaltar desde logo a crítica de Alessandro Baratta ${ }^{41}$ ao postulado da igualdade, que informa que a lei penal é igual para todos. Isso porque a criminalidade não é o comportamento de uma minoria, mas da maioria dos cidadãos, e que, além disso, é um status atribuído a determinados indivíduos por parte daqueles que detêm o poder de criar e aplicar a lei penal, a partir de mecanismos seletivos,

39 ZAFFARONI, Eugenio Raúl. O inimigo no direito penal, 2007, p. 172.

40 NIETZSCHE, Friedrich. Aurora: reflexões sobre os preconceitos morais. São Paulo: Companhia das Letras, 2004, p. 21.

41 BARATTA, Alessandro. Criminologia Crítica e Crítica do Direito Penal: introdução à sociologia do direito penal. 6ed. Rio de Janeiro: Editora Revan, 2011, p.112. sobre cuja estrutura e funcionamento o antagonismo dos grupos sociais têm influência fundamental.

$\mathrm{O}$ reducionismo penal pretende um Direito Penal mínimo que, no entender de Amilton Bueno de Carvalho, é um sonho dos criminalistas críticos, ao buscar uma real ultima ratio e não mero discurso de ultima ratio: "mínimo que seja mínimo mesmo e não mínimo com o discurso de mínimo para justificar o máximo, como se todo comportamento tido como 'imoral' merecesse ser alcançado pelas agências penais". ${ }^{42}$

\section{A falsa universalidade do bem jurídico: O QUE(M) se pretende proteger?}

Uma das causas fundamentais da criminalização de grupos cada vez mais amplos de pessoas é, conforme Francisco Muñoz Conde,${ }^{43}$ encontrada nas próprias normas jurídicas, que manipuladas adequadamente por grupos de pressão minoritária e detentores do poder, dificultam a coexistência pacífica dos distintos sistemas de valores de uma mesma comunidade e aumentam a luta entre os sistemas dominantes e os que não o são.

Assim, ao invés de a norma penal funcionar como um instrumento motivador determinante dos comportamentos das pessoas e, diante disso, constituir um fator integrador dos diferentes grupos sociais, protegendo bens jurídicos fundamentais ao todo, possui um efeito invertido, favorecedora e até mesmo causadora da marginalização, já que, por vezes, é manipulada para proteger interesses minoritários. ${ }^{44}$

E a norma penal é instrumento para implementação dessa manipulação? Também o é. Não se pode perder de vista que se está tratando da soma dos exercícios de poder de todas as agências que operam no processo de criminalização, ${ }^{45}$ ou seja, do sistema penal. Isso não quer dizer, porém, que a palavra "sistema" indica uma operação homogênea e organizada

42 CARVAlHO, Amilton Bueno de. Direito Penal a Marteladas: algo sobre Nietzsche e o Direito. Rio de Janeiro: Editora Lumen Juris, 2013, p. 40.

43 MUÑOZ CONDE, Francisco. Função motivadora da norma penal e “marginalização”. Revista Justitia. São Paulo. 48 (135): 32-38, jul./set. 1986 p. 35 .

44 MUÑOZ CONDE, Francisco. Função motivadora da norma penal e “marginalização", 1986, p. 32-33.

45 ZAFFARONI, Eugenio Raúl. Em busca das penas perdidas, 2012, p. 144. 
das agências de controle penal. Por vezes, estas agências invariavelmente exercem seus respectivos papéis em descompasso umas com as outras e de forma fragmentada, fato que impede conceber o "sistema penal" no sentido de organização.

Desse modo, é fundamental a contribuição da legislação penal na seleção dos bens jurídicos penalmente protegidos e dos comportamentos ofensivos a esses bens, descritos nos tipos penais, ou seja, no processo de criminalização. A criminalização primária consiste no ato de selecionar bens jurídicos relevantes que mereçam proteção impostas pelo direito penal material. Quem está encarregado de efetuar a escolha dos bens jurídicos penalmente relevantes a ponto de serem protegidos pelo Direito Penal no Brasil, ou seja, legislar sobre Direito Penal, são os deputados e senadores, enfim, o Congresso Nacional.

O problema é que, em grande medida, a legislação penal é seletiva, estigmatizante e promove a degradação na figura social de sua clientela. ${ }^{46}$ E essa seleção, estigmatização e degradação ocorrem mediante as diversas formulações técnicas dos tipos penais, aliadas às espécies de conexão que eles determinam com o mecanismo das agravantes/atenuantes e qualificadoras/privilegiadoras. Vê-se, por exemplo, que o furto simples, tipificado no artigo 155, caput, do Código Penal é capitulação rara nas peças acusatórias do nosso país. Quase sempre esse crime é qualificado por uma daquelas situações apresentadas no $\S 4^{\circ}$. Esse tipo de delito é, notadamente, praticado por pessoas pobres, razão pela qual a aplicação de qualificadoras que majoram a pena vem bem a calhar.

Percebe-se, ainda, que as malhas dos tipos penais são, em geral, mais sutis no caso dos delitos próprios de "colarinho branco". Por isso, na formulação dos tipos penais, é possível denotar um critério puramente "político" de intervenção altamente seletiva aos "inimigos políticos" e à preservação dos "amigos políticos" $"$ mesmo que pratiquem exatamente o mesmo comportamento.

Diante disso, é possível dizer que a Legislação Penal não é expressão de um consenso geral de vontades, senão reflexo de um modo de produção e uma

46 BATISTA, Nilo. Introdução crítica ao direito penal brasileiro. Rio de Janeiro: Revan, 1990, p. 26.

47 ZAFFARONI, Eugenio Raúl. Em busca das penas perdidas, 2012, p. 40. forma de proteção de interesses de classe, a dominante, no grupo social a que esse direito e Estado pertencem. O Direito Penal não protege por igual todos os bens relativos a que têm igual interesse todos os cidadãos; tampouco a lei penal é igual para todos os sujeitos, independentemente da danosidade social e da gravidade das infrações à lei penal por eles realizadas. ${ }^{48}$ Dirige-se, o sistema, à contenção de grupos bem determinados e não a "repressão de delitos", ${ }^{49}$ como declaradamente se propõe.

\section{A Concepção Crítica Criminológica: a superação da criminologia positivista pela Criminologia da Reação Social}

A criminologia da reação social, ou labelling approach, ou ainda, teoria do etiquetamento, teve como seu fundador Howard Becker, que na obra Outsiders, realizou estudos da sociologia do desvio.

Segundo Howard Becker, ${ }^{50} \mathrm{o}$ fato central acerca do desvio é que ele é criado pela sociedade, não no sentido em que é comumente compreendido, ou seja, de que as causas do desvio estão na situação social do desviante ou em fatores sociais que incitam sua ação. Pelo contrário: grupos sociais criam o desvio ao fazer as regras cuja infração constitui desvio, e ao aplicar essas regras a pessoas particulares e ao rotulá-las como outsiders.

Para Becker, ${ }^{51}$ o desvio não é uma qualidade do ato que a pessoa comete, mas uma consequência da aplicação por outros de regras e sanções a um "infrator". O desviante é alguém a quem esse rótulo foi aplicado com êxito, de modo que o comportamento desviante é aquele que as pessoas rotulam como tal.

O labelling aproach, segundo Baratta, ${ }^{52}$ parte da premissa de que não se pode entender a criminalidade se não se estuda a ação do direito penal, que a define e reage contra ela, iniciando pelas normas abstratas até a ação das instâncias oficiais (polícia,

\footnotetext{
48 MUÑOZ CONDE, Francisco. Direito penal e controle social. Rio de Janeiro: Forense, 2005, p. 30-31.

49 ZAFFARONI, Eugenio Raúl. Em busca das penas perdidas, 2012, p. 40. 50 BECKER, Howard S. Outsiders: estudos de sociologia do desvio. Rio de Janeiro: Zahar, 2009, p.20.

51 BECKER, Howard S. Outsiders, 2009, p.20.

52 BARATTA, Alessandro. Criminologia Crítica e Crítica do Direito Penal, 2011, p.86.
} 
juízes, instituições penitenciárias), de modo que o status social do delinquente pressupõe o efeito da atividade das instâncias oficiais de controle social da delinquência. Isso porque não é tratado como delinquente aquele que, apesar de ter realizado o mesmo comportamento reprovável, não é alcançado pela ação das referidas instâncias.

$\mathrm{O}$ autor ${ }^{53}$ esclarece que o conteúdo da ideologia da defesa social é reconstruível numa série de princípios, que encontram direta confrontação crítica nas teorias sociológicas atuais sobre a criminalidade.

De acordo com o princípio da legitimidade, o Estado está legitimado para reprimir a criminalidade, por meio de instâncias oficiais de controle social (legislação, polícia, magistratura, instituições penitenciárias). Já o princípio do bem e do mal estabelece que o delito é um dano para a sociedade, sendo então o delinquente um elemento negativo do sistema social. Assim, o desvio criminal é, pois, o mal; a sociedade constituída, o bem. ${ }^{54}$

O princípio da culpabilidade dispõe que o delito é expressão de uma atitude interior reprovável, pois é contrária aos valores e normas presentes na sociedade, mesmo antes de serem reguladas por lei. Já o princípio da finalidade ou da prevenção diz que a pena não tem somente a função de retribuir, mas de prevenir o crime, e como sanção concreta, tem a função de ressocializar o delinquente. ${ }^{55}$

Por sua vez, o princípio da igualdade estabelece que a criminalidade é a violação da lei penal e, como tal, é o comportamento de uma minoria desviante, de modo que a lei penal é igual para todos. Assim, a reação penal se aplica de modo igual aos autores de delitos. Finalmente, o princípio do interesse social e do delito natural informa que o núcleo central dos delitos definidos nos códigos penais das nações civilizadas representa ofensa de interesses fundamentais, de condições essenciais à existência de toda sociedade. ${ }^{56}$

Baratta acrescenta que o conceito de defesa social corresponde a uma ideologia caracterizada por uma concepção abstrata de sociedade, entendida como uma totalidade de valores e interesses. Uma

\footnotetext{
53 ibidem, p.42.

54 idem.

55 idem.

56 idem.
}

teoria adequada de criminalidade, sobre a qual se pretende atualmente basear um novo modelo integrado de ciência do direito penal, é caracterizada por elementos antitéticos à ideologia da defesa social: em primeiro lugar, essa teoria trabalha com um conceito situado, ou seja, com uma abstração determinada correspondente a específicas formações econômico-sociais e aos problemas e contradições que lhe são inerentes. ${ }^{57}$

As ideologias da reação social e da criminologia crítica deslocaram o foco da análise do fenômeno criminal, saindo do sujeito criminalizado para o sistema penal e os processos de criminalização e, por fim, para todo o sistema da reação social ao desvio. ${ }^{58}$

Para Vera Regina Pereira de Andrade, convém falar da criminalização e do criminalizado, e não da criminalidade e do criminoso. O labelling aproach, modelado pelo interacionismo simbólico e a etnometodologia como esquema explicativo da conduta humana (o construtivismo social), parte dos conceitos de "conduta desviada" e "reação social" para formular sua principal tese: a de que o desvio e a criminalidade não são uma qualidade intrínseca da conduta ou uma entidade ontológica preconstituída à reação social e penal, mas uma qualidade ou etiqueta atribuída a determinados sujeitos por intermédio de complexos processos de interação social; isto é, de processos formais e informais de definição e seleção. ${ }^{59}$

Zaffaroni destaca que o sistema penal seleciona pessoas ou ações, além de criminalizar certas pessoas segundo sua classe ou posição social. Segundo o autor, há uma evidente demonstração de que nem todos são suscetíveis ao sistema penal, o qual se organiza por estereótipos que colhem caracteres dos setores marginalizados, sendo que a criminalização gera a rejeição do etiquetado, bem como, daquele que se solidariza ou contata com o estigmatizado. ${ }^{60}$

Segundo Foucault, a infração lança o indivíduo contra todo o corpo social; a sociedade passa,

\footnotetext{
57 BARATTA, Alessandro. Criminologia Crítica e Crítica do Direito Penal, 2011 , p.48.

58 ibidem, p.49.

59 ANDRADE, Vera Regina Pereira. Do paradigma etiológico ao paradigma da reação social: mudança e permanência de paradigmas criminológicos na ciência e no senso comum, p. 28.

60 ZAFFARONI, Eugênio Raúl; PIERANGELI, José Henrique Manual de Direito Penal Brasileiro, volume 1: parte geral. 6ed. rev. atual. São Paulo: Editora Revista dos Tribunais, 2006, p. 67.
} 
então, a sentir-se legitimada para levantar-se em peso contra ele, para puni-lo. Uma luta desigual: de um lado, todas as forças, todo o poder, todos os direitos. Constrói-se, assim, um formidável direito de punir, pois o infrator se torna o inimigo comum: até pior, um traidor, um monstro. ${ }^{61}$

Para Zaffaroni, praticamente não existe conduta - nem mesmo as ações mais privadas - que não seja objeto de controle por parte dos órgãos do sistema penal, ou daqueles que usam sua executividade para reforçar sua vigilância, embora mais vulneráveis àquelas ações realizadas em público, o que aumenta a seletividade da vigilância, em razão da divisão do espaço urbano, deixando mais expostos os segmentos mais carentes. ${ }^{62}$

\section{A Crise do Discurso de Justificação do Direito Penal quanto a seus objetivos declarados}

Conforme o estudo das teorias funcionalistas, as funções do Direito Penal dependerão do paradigma funcionalista adotado. A concepção cunhada por Roxin, que trata de um funcionalismo moderado tem prevalecido no plano doutrinário ocidental.

Porém, para que o Direito Penal atinja essas funções protetoras de bens jurídicos essenciais à coexistência, deve estar ancorado em alguns pilares que lhe dão sustentação. Esses pilares revelam-se por meio de princípios de Direito Penal, quais sejam: legitimidade, bem e mal, culpabilidade, finalidade ou prevenção, igualdade e interesse social.

Segundo Luigi Ferrajoli, ${ }^{63}$ ainda se encontram em voga as justificações da punição baseadas nas doutrinas utilitaristas, que consideram a pena enquanto meio para se evitar futuros delitos: prevenção especial (que busca alcançar o autor do crime e corrigi-lo) e prevenção geral (que atribue o fim preventivo aos cidadãos em geral) e as retributivistas, que buscam uma aproximação da pena com o castigo, a retribuição.

61 FOUCAULT, Michel. Vigiar e punir: nascimento da prisão, 2011, p. 86 62 ZAFFARONI, Eugenio Raúl. Em busca das penas perdidas, 2012, p. 25. 63 FERRAJOLI, Luigi. Direito e Razão: teoria do garantismo penal. São Paulo: Editora Revista dos Tribunais, 2002, p. 204.
Para Carvalho, ${ }^{64}$ a pena está desacreditada como possibilidade recuperadora do cidadão e não atemoriza ninguém. E acrescenta: a retórica da impunidade como causa da criminalidade é discurso improvado e improvável.

Zaffaroni6 $^{65}$ destaca que o sistema penal é um verdadeiro embuste, ao pretender um poder que não possui e ocultando o verdadeiro poder que exerce, de modo que se torna óbvio que o sistema penal está estruturalmente montado para que a legalidade processual não opere e, sim, para exercer seu poder com elevado grau de arbitrariedade seletiva dirigida, evidentemente, aos setores mais vulneráveis.

Conforme o autor referido, ${ }^{66}$ é bastante claro que enquanto o discurso jurídico-penal racionaliza cada vez menos, justamente pelo esgotamento de seu arsenal de ficções gastas, os órgãos do sistema penal exercem seu poder para controlar um marco social cujo principal signo é a morte em massa. E acrescenta o autor que não é mais possível argumentar que tal momento crítico se trata de um momento de transitoriedade, enquanto se aguarda pelo desenvolvimento progressivo.

Até porque, a seletividade, a reprodução da violência, a criação de condições para maiores condutas lesivas, a corrupção institucionalizada, a concentração de poder, enfim, são características estruturais, e não conjunturais, do exercício de poder de todos os sistemas penais. ${ }^{67}$

O princípio da legitimidade seria atingido justamente pela relação variável do processo de criminalização de acordo com a posição social do acusado e indica uma relatividade na proteção penal dos bens jurídicos. ${ }^{68}$

Já a concepção maniqueísta, dividindo a sociedade entre o bem e o mal, igualmente se desconstrói, justamente pela revisão crítica da criminologia de orientação biológica e caracterológica, de modo que evidentemente as causas do desvio não devem ser pesquisadas nem em fatores bioantropológicos e

64 CARVALHO, Amilton Bueno de. Direito Penal a Marteladas, 2013, p.82. 65 ZAFFARONI, Eugenio Raúl. Em busca das penas perdidas, 2012, p. 27. 66 ibidem, p. 13.

67 ZAFFARONI, Eugenio Raúl. Em busca das penas perdidas, 2012, p. 13. 68 BARATTA, Alessandro. Criminologia Crítica e Crítica do Direito Penal, 2011, p.50. 
naturais, nem em uma situação patológica da estrutura social. ${ }^{69}$

A negação do princípio da culpabilidade, ou seja, da responsabilidade ética individual como base do sistema penal, tem a ver com o fato de que os mecanismos de aprendizagem e de interiorização de regras e modelos de comportamento, que estão na base da delinquência e, particularmente, das carreiras criminosas, não diferem dos mecanismos de socialização por meio dos quais se explica o comportamento normal. ${ }^{70}$

O princípio do fim ou da prevenção é colocado em dúvida, em particular a concepção educativa da pena, uma vez que a intervenção do sistema penal, especialmente a pena privativa de liberdade, antes de ter um efeito reeducativo sobre o delinquente determina, na maior parte dos casos, uma consolidação da identidade desviante do condenado e o seu ingresso em uma verdadeira carreira criminosa. ${ }^{71}$

Conforme já mencionado acima, por ocasião do estudo do funcionalismo reducionista, o princípio da igualdade, pilastra da ideologia do Direito Penal, se mostra igualmente desconstruído, uma vez que a criminalidade é um status atribuído a alguns sujeitos por parte de outros sujeitos, aqueles que detêm o poder de criar e aplicar a lei penal, com base em critérios ligados à estratificação social e à estrutura antagônica da sociedade. ${ }^{72}$

Igualmente deslegitimado, o discurso ideológico do Direito Penal no que se refere ao princípio do interesse social ou delito natural, uma vez que a criminalidade, segundo o paradigma da reação social, é uma realidade criada pelo processo de criminalização, orientado justamente por aqueles que têm interesse e poder de influir nesse processo. Enfim, os interesses protegidos pelo Direito Penal não são, evidentemente, interesses comuns a todos os cidadãos. ${ }^{73}$

De acordo com Loïc Wacquant, ${ }^{74}$ à medida que o Estado se desincumbe da economia e se desfaz de

69 ibidem, p.49.

70 ibidem, p.76.

71 ibidem, p.90.

72 ibidem, p.113.

73 BARATTA, Alessandro. Criminologia Crítica e Crítica do Direito Penal, 2011, p. 119.

74 WACQUANT, Loïc. Punir os pobres: a nova gestão da miséria nos Estados Unidos [A onda punitiva]. Tradução de Sérgio Lamarão. Rio de Janeiro: Revan, 2007, p. 61. sua missão de proteção social, seu poder de penetrar nas populações sob seu jugo e de reger seus comportamentos, opera cada vez mais a partir das redes tecidas por seu aparelho repressivo. Além disso, as categorias ditas deserdadas, presas preferenciais do sistema penal, já estão, de certo modo, colocadas sob as vistas da burocracia da assistência social, que supervisiona sem tréguas suas condutas rotineiras e suas vidas íntimas.

Andrade $^{75}$ chega à conclusão de que a criminalidade é um fenômeno normativo, impossível de ser conhecido do ponto de vista fenomenológico, de modo que a partir de uma desconstrução epistemológica se verifica o quanto a Criminologia positivista contribui para a produção e reprodução de uma imagem estereotipada e preconceituosa da criminalidade e do criminoso, vinculada aos baixos estratos sociais. Essa perspectiva de verdadeira "ciência do controle social" condiciona a seletividade do sistema penal, de secular vigência no senso comum em geral e dos operadores do sistema penal em particular.

\section{A questão da prevenção geral positiva}

Dispõe o artigo $1^{\circ}$ da Lei n. 7.210, de 11 de julho de 1984, que institui a Lei de Execução Penal: ${ }^{76}$ "a execução penal tem por objetivo efetivar as disposições de sentença ou decisão criminal e proporcionar condições para a harmônica integração social do condenado e do internado".

Trata o dispositivo mencionado da prevenção especial positiva, que nada mais é que a correção, reeducação, ressocialização, enfim, reintegração do condenado, termos usados indiscriminadamente como sinônimos do objetivo da pena.

Zaffaroni ${ }^{77}$ acrescenta que a prevenção especial não pode consistir em qualquer constrangimento físico. Tampouco deve consistir em alguma "reeducação" ou "tratamento" que pretenda visualizar o homem como um ser carente em sentido "moral" ou

\footnotetext{
75 ANDRADE, Vera Regina Pereira. Do paradigma etiológico ao paradigma da reação social, p.35.

76 BRASIL. Lei Federal 7.210, de 11 de julho de 1984. Institui a Lei de Execução Penal.

77 ZAFFARONI, Eugênio Raúl; PIERANGELI, José Henrique. Manual de Direito Penal Brasileiro, 2006, p. 96.
} 
"médico", ou seja, não pode o Direito Penal de um Estado que respeita os Direitos Humanos considerar o criminalizado numa condição de inferioridade. Ademais, a prevenção especial não pode ser rígida, mas uma forma de resolver os conflitos manifestados pela criminalização.

Aury Lopes Júnior, ${ }^{78}$ acerca do objetivo da pena, esclarece que o Direito Penal nasce não como evolução, senão como negação da vingança, por esse motivo, não há que se falar em "evolução histórica" da pena de prisão. A pena não está justificada pelo fim de vingança, senão pelo de impedi-la por completo. No sentido cronológico, a pena substituiu a vingança privada, não como evolução, mas como negação, pois a história do Direito Penal e da pena é uma longa luta contra a vingança.

Para Foucault, ${ }^{79}$ punir será uma arte dos efeitos quando calcular a pena não em função do crime, mas de sua possível repetição; visar não a ofensa passada, mas a desordem futura; fazer de tal forma que o malfeitor não possa ter desejo de recomeçar, nem seja possível que tenha imitadores; mais que opor a enormidade da pena à enormidade da falta, é preciso ajustar uma à outra as duas séries que seguem o crime, quais sejam, seus próprios efeitos e os da pena. Enfim, conclui o autor que "um crime sem dinastia não clama castigo".

Segundo Foucault, ${ }^{80}$ a prisão, região mais sombria do aparelho da justiça, é o local onde o poder punitivo "organiza silenciosamente um campo de objetividade em que o castigo poderá funcionar em plena luz como terapêutica e a sentença se inscrever entre os discursos do saber".

Foucault ${ }^{81}$ destaca, ainda, que a crítica ao sistema prisional vem de longa data, tendo em vista que as prisões não diminuem a taxa de criminalidade, pelo contrário: a quantidade de crimes e de criminosos permanece estável ou aumenta. Ademais, a detenção provoca a reincidência, pois, depois de sair da prisão, têm-se mais chance de voltar para ela. Enfim, segundo o autor, a prisão fabrica indiretamente delinquentes, ao fazer cair na miséria a família do detento,

\footnotetext{
78 LOPES JR, Aury. Direito Processual Penal. 9ed rev. e atual. São Paulo: Saraiva, 2012, p. 60.

79 FOUCAULT, Michel. Vigiar e punir: nascimento da prisão, 2011, p. 89.

80 idem.

81 ibidem, p. 254.
}

pois "a mesma ordem que manda para a prisão o chefe de família reduz cada dia a mãe à penúria, os filhos ao abandono, a família inteira à vagabundagem e à mendicância".

Carvalho, ${ }^{82}$ ao falar da emergência da "criminalidade incontrolada", afirma que o sistema jurídico-penal continua a acreditar que leis cruéis derrotarão a criminalidade. A crença no ideal "lei-prisão" como resposta à criminalidade carrega consequências agressivas, entre as quais: aumento acentuado das penas, criação irracional de novos tipos, penas mais severas e desproporção entre crime-castigo, endurecimento do sistema, de modo que a pena passa a ser mero castigo e retribuição. Sem contar a banalização da prisão provisória e da transformação constante de crimes em hediondos.

$\mathrm{O}$ autor $^{83}$ faz uma crítica à própria sociedade pelas condições animalescas dos cárceres, ao mencionar que ninguém se sente responsável; todos estão convencidos de que estão apenas a cumprir ordens, desde o acusador cumprindo seu dever de denunciar, passando pelo juiz, que apenas está cumprindo a lei, nada tendo ele com a execução, culminando no carcereiro e no próprio Estado, tido como mera abstração, acusado de não cumprir suas obrigações legais por ele próprio.

Servir-se da prisão como um "aspirador social" para limpar as escórias produzidas pelas transformações econômicas em andamento, e remover os rejeitos da sociedade de mercado do espaço público, quais sejam, delinquentes ocasionais, desempregados e indigentes, pessoas sem-teto e imigrantes sem documentos, toxicômanos, deficientes e doentes mentais deixados de lado em razão da displicência da própria rede de saúde e assistência social, além de jovens de origem popular, condenados a uma vida de empregos marginais e de pequenos ilícitos, segundo Wacquant, ${ }^{84}$ é uma aberração, no sentido estrito do termo, um erro de julgamento do sistema político e penal. Enfim, o recurso automático do encarceramento para debelar as desordens humanas é um

\footnotetext{
82 CARVAlHO, Amilton Bueno de. Direito Penal a Marteladas, 2013, p. 44.

83 CARVAlHO, Amilton Bueno de. Direito Penal a Marteladas, 2013, p. 125.

84 WACQUANT, Loïc. Punir os pobres, 2007, p. 455.
} 
remédio que, em muitos casos, só faz agravar o mal que supostamente curaria.

Ferrajoli ${ }^{85}$ chega a propor a abolição da pena carcerária, ressaltando que a privação da liberdade já não parece idônea, para não dizer desnecessária, para satisfazer as razões que justificam a sanção penal; nem a prevenção de delitos, considerado o caráter criminógeno das prisões, hoje destinadas a funcionar como escolas de delinquência e de recrutamento da criminalidade organizada; nem a prevenção da vingança privada, atualmente satisfeita bem mais pela rapidez dos processos e publicidade das condenações, que pela expiação da prisão.

Baratta $^{86}$ entende possível uma proposta de verdadeira intervenção mínima, com considerável descriminalização, redução radical da pena de prisão e a recuperação de todos os limites do chamado "direito penal liberal", sem nenhuma pretensão paradigmática que legitime o resto do sistema penal.

Ressalta-se, neste sentido, que a história penal mostra que em nenhum momento e em nenhuma sociedade, a prisão soube cumprir a sua suposta missão de recuperação e de reintegração sociais, numa perspectiva de redução da reincidência. Sem contar que o próprio sistema penitenciário, desde a arquitetura das instalações, passando pela indigência dos recursos institucionais e a falta de medidas concretas de ajuda no momento em que o preso é libertado se opõe a suposta função de reformar o detento. ${ }^{87}$

Para Carvalho, ${ }^{88}$ o discurso mais recorrente como justificador da existência do cárcere, é o de que ele que procura recuperar o humano que tenha sido condenado pela prática de um ato que, em certo momento histórico, é tipificado como crime, importando somente que esteja tipificado. Neste caso, como bem registrou Nietzsche, "só se podem elevar os homens que não tratamos com desprezo; o desprezo moral é um aviltamento e um prejuízo maior do que qualquer crime".

85 FERRAJOLI, Luigi. Direito e Razão, 2002, p.330.

86 BARATTA, Alessandro. Criminologia Crítica e Crítica do Direito Penal, 2011, p.94.

87 WACQUANT, Loïc. Punir os pobres, 2007, p.459.

88 CARVALHO, Amilton Bueno de. Direito Penal a Marteladas, 2013, p. 107.

\section{A redução da maioridade penal como instrumento (i)legítimo de redução da criminalidade}

Partindo da premissa de que o Direito Penal não atemoriza, pois sua existência não tem evitado crimes, além da promessa de ressocialização ou recuperação jamais ter se concretizado, urge sua desbanalização, com a redução drástica de seu alcance..$^{89}$

$\mathrm{Na}$ esfera dos direitos da criança e do adolescente, resguardados pela Lei n. 8.069, de 13 de julho de 1990, que institui o Estatuto da Criança e do Adolescente, ${ }^{90}$ pode-se, por analogia, dizer que permanece no senso comum o paradigma da criminologia positivista, que já deveria ter dado lugar a um genuíno Direito Infracional, baseado em garantias constitucionais.

Ocorre que, na prática, tem-se aplicado um verdadeiro "direito penal juvenil" baseado na cultura higienista, seletiva e, enfim, Lombrosiana do revogado Código de Menores. Segundo Vera Malaguti Batista, ${ }^{11}$ é justamente a partir da época do sistema menorista (anos 1920) que a palavra menor passa a associar, definitivamente, crianças pobres, a serem tuteladas pelo Estado, para a preservação da ordem e o asseguramento da modernização capitalista.

Batista relembra do sistema conhecido como SAM - Serviço de Assistência ao Menor, que existiu nos anos 1930 até 1945, de onde surgiu a ideia de "orientação profissional" como parte do processo de recuperação de adolescentes, de modo que o ensino profissionalizante parece ser a única alternativa da juventude pobre: aspirar à integração por baixo no mercado de trabalho é a única perspectiva possível..$^{92}$

Já a Doutrina da Segurança Nacional trazida pelo Golpe Militar de 1964 traz com o novo código menorista, segundo Batista, ${ }^{93}$ a cultura da "situação irregular", como um estado de patologia social, sendo um dos eixos desse sistema o não reconhecimento do menor como pessoa, mas como um sujeito a ser tutelado.

\footnotetext{
89 ibidem, p.46.

90 BRASIL. Lei Federal 8.069, de 13/07/1990. Dispõe sobre o Estatuto da Criança e do Adolescente e dá outras providências.

91 BATISTA, Vera Malaguti. Difíceis ganhos fáceis, 2003, p. 69.

92 ibidem, p. 72.

93 BATISTA, Vera Malaguti. Difíceis ganhos fáceis, 2003, p. 79.
} 
De fato, os adolescentes não são verdadeiramente reconhecidos como sujeitos de direito, mas como sujeitos a serem tutelados pelo Estado, em sua condição peculiar de pessoas em desenvolvimento, conforme estabelecido no Estatuto da Criança e do Adolescente pela Doutrina da Proteção Integral. A construção desse marco filosófico teve como base a mudança de paradigma nos estudos da Criminologia já mencionados, com o objetivo de reunir ações de proteção e garantia dos direitos humanos de crianças e adolescentes.

Segundo Alexandre Morais da Rosa ${ }^{94}$ os estudos criminológicos, em seu paradigma atual, aparentemente impregnaram alguns de seus postulados no Estatuto da Criança e do Adolescente, ao buscar a redução de encaminhamento de casos ao Judiciário ou ao tentar evitar a privação de liberdade, justamente por não acreditar no discurso de ressocialização. Isso pode ser verificado na excepcionalidade da aplicação da medida de internação ou mesmo na brevidade de seu cumprimento, além da previsão de alternativas consubstanciadas, por exemplo, nas medidas socioeducativas de obrigação de reparar o dano e prestação de serviços à comunidade.

Contudo, segundo o autor, ainda é priorizada pelos juízes, arraigados à visão menorista anterior, a medida de internação, até pela pouca compreensão existente de que as medidas socioeducativas têm avançado no sentido de atender ao discurso oficial de oportunizar condições de reflexão e amadurecimento sobre condutas contrárias ao convívio social. Fica evidente o olhar seletivo determinando maior punição aos adolescentes provenientes das periferias, e a remissão aos "filhos da classe média", de modo a fortalecer o sistema punitivo e ferindo a proposta avançada e afinada com os direitos humanos pretendida no Estatuto da Criança e do Adolescente. ${ }^{95}$

Conforme já se verificou no decorrer deste estudo, a lei determina qual conduta é considerada crime, ficando a cargo das agências de poder do sistema penal dizer quem é o criminalizado. $\mathrm{O}$ discurso repressor se aproxima do Direito Infracional, na perspectiva de apontar tecnicamente quem é o desviante,

94 MORAIS DA ROSA, Alexandre; LOPES, Ana Cristina Brito. Introdução crítica ao ato infracional: princípios e garantias constitucionais. Rio de Janeiro: Lumen Juris, 2011, p. 19.

95 ibidem, p. 20. bem como prescrever o tratamento ao "anormal", entendido como criminoso/infrator e, numa sociedade à margem do capitalismo, todos os que pretensamente prejudicam essa engrenagem (mendigos, ébrios, vadios que não estudam etc.). Surge, então, a diferenciação: para o rico, tratamento; para o pobre, exclusão. ${ }^{96}$

Mário Luiz Ramidoff ${ }^{97}$ ressalta os sistemas de garantias trazidos pelo Estatuto da Criança e do Adolescente, com o objetivo de atendimento das novas exigências sociais, identificação dos novos sujeitos de direito, estabelecimento de proteções diferenciadas, asseguramento de toda sorte de preconceito, exploração, abandono e negligência. Tanto que o próprio texto constitucional, ${ }^{98} \mathrm{em}$ seu art. 227 estabelece a responsabilidade comum e concorrente, de igual sorte que compete à família, à sociedade e ao Estado o alcance de tais metas relacionadas aos sistemas de garantias.

Desta forma, não se pode tratar o Direito Infracional como sinônimo de Direito Penal Juvenil, muito menos pretender estender os efeitos do Direito Penal aos adolescentes, justamente por se tratar de uma justiça especializada baseada na sistemática do Estatuto da Criança e do Adolescente, com objetivo jurídico-protetivo de assegurar os direitos afetos à criança e ao adolescente, por meio do "sistema de garantias", que não deve guardar nenhuma relação com outros sistemas. ${ }^{99}$

Ramidoff $^{100}$ ainda refere que um exemplo do enfraquecimento identitário da teoria jurídico-protetiva viria justamente de uma indevida submissão integrativa com base na interpretação ideológica repressivo-punitiva, tão particular ao Direito Penal.

Essa perigosa aproximação teórico-pragmática com a ideologia do sistema penal busca legitimar a ressignificação punitiva e repressora, ou seja, limitação, castigo, dor, dos comportamentos e medidas legais a serem aplicadas. Filiar-se aos ditames

\footnotetext{
96 MORAIS DA ROSA, Alexandre; LOPES, Ana Cristina Brito. Introdução crítica ao ato infracional, 2011, p. 23.

97 RAMIDOFF, Mário Luiz. Lições de Direito da Criança e do Adolescente: ato infracional e medidas socioeducativas. Curitiba: Juruá, 2011, p. 45. 98 BRASIL. Constituição da República Federativa do Brasil: promulgada em 05/10/1988.

99 RAMIDOFF, Mário Luiz. Lições de Direito da Criança e do Adolescente, 2011, p. 47.

100 idem.
} 
da racionalidade da dogmática do Direito Penal e a todo seu discurso deslegitimado, seria, portanto, um retrocesso ideológico ao menorismo. ${ }^{101}$

As proposições legislativas de redução da maioridade penal constituem-se num retrocesso político ideológico, visto que a idade da imputabilidade penal é fruto de avanços civilizatórios e humanitários democraticamente alcançados. Assim, a idade da maioridade penal demanda superação de conjecturas comportamentais que são delimitadas a partir da prática do ato infracional. A responsabilização diferenciada é um compromisso com a formação educacional da criança e do adolescente, dada sua condição pedagógica elementar que é indispensável para a construção de projetos de vida responsáveis. Assim, o exercício da cidadania dos jovens depende muito mais do respeito de todos do que simplesmente de mais castigo (punição). ${ }^{102}$

Baratta ${ }^{103}$ menciona que o sistema dos direitos das crianças e dos adolescentes foi conduzido, até o momento, por duas emergências: a emergência do risco-abandono e a emergência criminal. Em consequência, prevaleceram políticas públicas de resposta contingencial a essas urgências, e não políticas públicas básicas.

Assim, não é verdade que a resposta protetiva à emergência risco-abandono é o álibi para a resposta repressiva à emergência criminal; segundo Baratta, ${ }^{104}$ é verdade que ambas as respostas emergenciais são a desculpa da opinião pública e das instituições para as graves deficiências das políticas públicas de base. Infelizmente, é com base nas políticas públicas emergenciais em que tem se ancorado o legislador para justificar disparates como a redução da maioridade penal.

Analisadas as teorias funcionalistas do Direito Penal, além dos paradigmas criminológicos que estudam o sistema penal, não se pode perder de vista que o processo de criminalização recruta de maneira desigual a população criminal. Enfim, a redução da idade penal causará, por meio da criminalização

101 idem.

102 RAMIDOFF, Mário Luiz. Lições de Direito da Criança e do Adolescente, 2011, p. 194.

103 BARATTA, Alessandro. "Prefácio". In: BATISTA, Vera Malaguti. Difíceis ganhos fáceis, 2003, p. 30.

104 idem. primária, a antecipação das mais diversas formas dissimuladas de isolamento social, senão do próprio encarceramento que se consubstanciam no desfecho final de um amplo processo de estigmatização da juventude brasileira. ${ }^{105}$

A promoção dos direitos afetos à infância e à adolescência impõe uma permanente reflexão sobre o conteúdo ideológico das normas jurídicas, impedindo que o discurso jurídico-penal, já deslegitimado como se viu com relação aos adultos incluídos no sistema penal, atinja com suas injustiças os adolescentes abarcados pelo Direito Infracional, devendo o pensamento criminológico crítico estar permanentemente alerta para, ao menos, oferecer argumentos para a manutenção da imputabilidade penal aos dezoito anos. ${ }^{106}$

Morais da Rosa ${ }^{107}$ propõe, nos mesmos moldes de Ferrajoli, um Direito Infracional mínimo, partindo da premissa que, se o Direito Penal, como ultima ratio, ou seja, como último recurso democrático perante a vergonhosa história das penas, e das medidas socioeducativas, estariam justificados os custos com as medidas socioeducativas nos casos em que os efeitos lesivos das condutas possam justificá-los. A consequência direta seria a redução de número de tipos, a diminuição do tempo das medidas socioeducativas, as quais, por serem muito prolongadas, excluem o sujeito da sociedade e são desumanas, mormente nas condições em que são aplicadas.

Acrescenta Morais da Rosa, ${ }^{108}$ fazendo menção a João Batista da Costa Saraiva, que a imputabilidade relativa aos menores de 18 anos é de natureza garantidora de direito individual, uma vez que a inimputabilidade não implica impunidade, já que estabelece medidas de responsabilização compatíveis com a condição peculiar de pessoas em desenvolvimento. Contudo, a impunidade tem sido a principal bandeira utilizada pelo exército contrário ao Estatuto e favorável à redução da maioridade penal, sem informar ao grande público que impunes já são muitos outros, os adultos, que como visto no decorrer deste

\footnotetext{
105 RAMIDOFF, Mário Luiz. Lições de Direito da Criança e do Adolescente, 2011, p. 197.

106 idem.

107 MORAIS DA ROSA, Alexandre; LOPES, Ana Cristina Brito. Introdução crítica ao ato infracional, 2011, p. 235.

108 MORAIS DA ROSA, Alexandre; LOPES, Ana Cristina Brito. Introdu-
} ção crítica ao ato infracional, 2011, p. 320. 
trabalho, não são atingidos igualitariamente pelo sistema penal.

Não se podem considerar impunes aqueles que cumprem as medidas socioeducativas em condições hoje iguais ou piores que a própria pena carcerária. Questões de terminologia ou a natureza do ato infracional são irrelevantes quando não se preserva aos adolescentes uma responsabilização diferenciada daquela aplicada aos adultos, nos moldes garantidos na Constituição Federal, no Estatuto da Criança e do Adolescente e no Código Penal. ${ }^{109}$

Segundo Morais da Rosa, ${ }^{110}$ tudo não passa de uma questão política, pois a natureza da medida socioeducativa terá a característica e a finalidade que será dada por quem estiver no poder político ou na atuação direta da aplicação da medida socioeducativa. De fato, a realidade tem mostrado a predominância de práticas puramente punitivas, aproximando a medida socioeducativa de internação ao caráter de pena privativa de liberdade, transmutando os adolescentes inimputáveis em verdadeiros imputáveis do Código Penal.

Em suma: as premissas ideológicas do Direito Penal não alcançam seus objetivos declarados por meio do sistema penal, dado o fator criminógeno e distante da ressocialização do condenado. O discurso seletivo-positivista está inculcado na mente do legislador e também na do juiz, embora a evidente deslegitimação do discurso jurídico-penal pelas concepções criminológicas com visão crítica já não seja nenhuma novidade.

Da mesma forma, os adolescentes ainda são submetidos à cultura menorista e higienista que, na prática, o Estatuto da Criança e do Adolescente ainda não conseguiu superar. A urgência da criminalidade não pode alicerçar alterações legislativas a ponto de suprimir direitos conquistados democraticamente, em especial a Doutrina da Proteção Integral que informa serem os adolescentes sujeitos em condição especial de desenvolvimento.

De fato, colocar os adolescentes ao alcance do falido sistema penal é aumentar o poder do Estado no uso de seu "aspirador de limpeza social". O Direito Penal não previne crimes e não ressocializa condenados. Certamente não o fará aumentando o alcance de sua clientela com a redução da maioridade penal.

Encerra-se o presente estudo com o pensamento de Galeano, ${ }^{111}$ que choca pela verdade e crueza e bem resume tudo que foi tratado até aqui:

Num mundo que prefere a segurança à Justiça, há cada vez mais gente que aplaude o sacrifício da Justiça no altar da segurança. Nas ruas das cidades são celebradas as cerimônias. Cada vez que um delinquente cai varado de balas, a sociedade sente um alívio na doença que a atormenta. A morte de cada malvivente surte efeitos farmacêuticos sobre os bem-viventes. A palavra farmácia vem de phármakos, o nome que os gregos davam às vítimas humanas nos sacrifícios oferecidos aos deuses nos tempos de crise.

\section{Considerações finais}

No presente artigo, intitulado "A redução da maioridade penal numa perspectiva criminológica: bom para que(m)?", verificou-se que o Direito Penal não é um instrumento legítimo para a contenção da criminalidade juvenil, de modo que se torna sem razão a redução da maioridade penal. Isso porque o Sistema Penal, em que o Direito está inserido, produz efeitos altamente prejudiciais a todo corpo social, pelo que sua presença somente se justificaria em situações realmente excepcionais.

Como visto, prevalece no âmbito doutrinário o discurso do Direito Penal como verdadeiro instrumento protetor de bens jurídicos, nos termos da concepção funcionalista moderada de Roxin. Contudo, o que ocorre na prática é a utilização do Direito Penal pelo Estado para selecionador determinadas pessoas, a despeito da impunidade de uma minoria de privilegiados.

A busca de uma realidade baseada na concepção reducionista de Zaffaroni, enfim, ancorada numa criminologia de visão crítica, resultaria num Direito Penal apto a legitimar essa seletividade que lhe é 
inerente, pelo que, hoje, deve ser ele convertido em instrumento de contenção mínima.

Ao contrário da propalada função protetora sustentada pelo sistema penal, verificou-se que o Direito Penal promove uma seleção de determinados crimes, que serão praticados por determinados grupos de pessoas. Nota-se uma discricionariedade ampla dos agentes de controle do Estado, pois grupos privilegiados da sociedade simplesmente não são atingidos por esta seleção, mitigando-se o princípio da igualdade, que informa que a lei penal é igual para todos.

Nesse aspecto, denota-se que a norma penal não funciona como um instrumento motivador determinante dos comportamentos das pessoas, mas, ao contrário, favorece e até mesmo causa mais marginalização, pois, conforme visto, a Legislação Penal é seletiva e estigmatizante. Afinal, esta não expressa um consenso de vontades, mas reflete o interesse da classe dominante. Não protege igualmente todos os bens a que têm interesse todos os cidadãos.

Enfim, destacou-se que o sistema penal é um verdadeiro embuste, ao pretender um poder que não possui e ocultando o verdadeiro poder que exerce, evidenciando-se que o sistema penal está estruturalmente montado para se retroalimentar. Ademais, a pena, objetivo último do sistema, conforme visto, não ressocializa, não reeduca, enfim, não reintegra o condenado.

Ainda que se acredite no ideal "lei-prisão" como solução à emergência da criminalidade, o que ocorre são consequências agressivas, entre as quais: o aumento acentuado das penas, a criação irracional de novos tipos, penas mais severas e desproporção entre crime-castigo, o endurecimento do sistema, de modo que a pena passa a ser mero castigo e retribuição. Isso sem mencionar as condições inaceitáveis das prisões, que só agravam o mal que supostamente se curaria com o encarceramento.

Neste sentido, se o Estado, utilizando-se do Direito Penal não protege legitimamente os bens jurídicos colocados sob sua tutela (desproporção entre a importância do bem jurídico $v s$ qualidade e quantidade das penas) e ainda, uma vez praticado o ilícito, não cumpre sua promessa de ressocialização ou recuperação dos condenados à privação de liberdade, realmente se faz necessária a redução do seu alcance conforme propõe o funcionalismo contencionista.

A visão trazida pela Criminologia Crítica é suficiente para demonstrar a deslegitimação do discurso jurídico-penal e do próprio Direito Penal, com a negação dos princípios que sustentam sua ideologia, constatando-se sua ineficácia como protetor de bens jurídicos e como instrumento capaz de socializar o sujeito que, eventualmente, transgride a norma, afinal, nem mesmo é operacionalizado de maneira a buscar os objetivos que declara.

Dessa forma, relacionando-se tais incapacidades ao público juvenil, qualquer proposta legislativa de redução da maioridade penal seria um retrocesso, pois culminaria na inclusão, num sistema falido, de adolescentes sem considerar sua condição especial de pessoas em desenvolvimento. Como visto, ainda, os adolescentes que seriam alcançados pelas agências de repressão representariam aqueles menores provenientes dos grupos sociais menos favorecidos economicamente, tendo em vista que o braço penal do Estado é incomensuravelmente mais vigoroso nestes setores, e qualquer aproximação do Direito Penal a esses sujeitos (des)protegidos seria ofensiva à conquista de direitos humanos elementares da Doutrina da Proteção Integral.

\section{REFERÊNCIAS}

ANDRADE, Vera Regina Pereira. Do paradigma etiológico ao paradigma da reação social: mudança e permanência de paradigmas criminológicos na ciência e no senso comum. Seqüência: Estudos Jurídicos e Políticos, v.16, n.30, p.24-36, 1995. Disponível em: <https://periodicos.ufsc.br/ index.php/sequencia/article/view/15819>. Acesso em: 16 setembro 2013.

BARATTA, Alessandro. Criminologia crítica e crítica do Direito Penal: introdução à sociologia do direito penal. 6.ed. Rio de Janeiro: Editora Revan, 2011.

Prefácio. In: BATISTA, Vera Malaguti. Difíceis ganhos fáceis: drogas e juventude pobre no Rio de Janeiro. Rio de Janeiro: Revan, 2003.

BATISTA, Vera Malaguti. Difíceis ganhos fáceis: drogas e juventude pobre no Rio de Janeiro. Rio de Janeiro: Revan, 2003.

BECKER, Howard S. Outsiders: estudos de sociologia do desvio. Rio de Janeiro: Zahar, 2009. 
BENITES, Afonso. 93\% dos paulistanos querem redução da maioridade penal. Folha de São Paulo. Disponível em: $<$ http://www1.folha.uol.com.br/fsp/cotidiano/104327-93dos-paulistanos-querem-reducao-da-maioridade-penal. shtml>. Acesso em: 17 abril 2013.

BITENCOURT, Cezar Roberto. Tratado de Direito Penal: parte geral. 19.ed.rev., ampl. e atual. São Paulo: Saraiva, 2013.

BUSATO, Paulo César; BASSO, Stephan Nascimento. Funções e missões do Direito Penal. In: BUSATO, Paulo César (Org.). Fundamentos de Direito Penal (Direito Penal baseado em casos). Curitiba: Juruá Editora, 2013.

BRASIL. Constituição (1988). Constituição da República Federativa do Brasil: promulgada em 05 de outubro de 1988.

Decreto-Lei 2.848, de 7 de dezembro de 1940 . Parte geral título I da aplicação da Lei Penal.

Lei n. 7.210, de 11 de julho de 1984. Institui a Lei de Execução Penal.

Lei n. 8.069, de 13 de julho de 1990. Dispõe sobre o Estatuto da Criança e do Adolescente e dá outras providências.

CARVALHO, Amilton Bueno de. Direito Penal a marteladas: algo sobre Nietzsche e o Direito. Rio de Janeiro: Editora Lumen Juris, 2013.

CHAVES JUNIOR, Airto; MENDES, Marisa Schmitt Siqueira. A miséria atrás das grades: a produção da criminalidade a partir da seletividade da norma penal. Revista Direito e Justiça - reflexões sociojurídicas, ano 9, n.12, março, 2009.

DOURADO, Kamilla. Mais de $\mathbf{9 0 \%}$ da população aprova a redução da maioridade penal. Disponível em: $<\mathrm{http}: / /$ r7.com/Embf >. Acesso em: 11 junho 2013.

FERRAJOLI, Luigi. Direito e razão: teoria do garantismo penal. São Paulo: Editora Revista dos Tribunais, 2002.

FOUCAULT, Michel. Vigiar e punir: nascimento da prisão. 39 ed. Rio de Janeiro: Editora Vozes, 2011.

GALEANO, Eduardo. De pernas pro ar: a escola do mundo ao avesso. Trad, Sérgio Faraco. Porto Alegre: L\&PM, 1999.

Os demônios do demônio. Disponível em: $<$ http:// titaferreira.multiply.com/reviews/item/143>. Acesso em: 12 novembro 2009.

GRECO, Luís. Princípio da ofensividade e crimes de perigo abstrato: uma introdução ao debate sobre o bem jurídico e as estruturas do delito. Revista Brasileira de Ciências Criminais, Ano 12, p. 89-90, jul./ago. 2004.
. Funcionalismo penal. In: BARRETO, Vicente de Paulo (Coord.). Dicionário de Filosofia do Direito. São Leopoldo/RS: Editora Unisinos; Rio de Janeiro: Editora Renovar. 2006.

GRECO, Rogério. Direito Penal do equilíbrio: uma visão minimalista do Direito Penal. 4. ed. Niterói: Impetus, 2009, p. 65.

MEROLLI, Guilherme. Fundamentos críticos de Direito Penal. Rio de Janeiro: Lumen Juris, 2010.

MIR PUIG, Santiago. Introducción las bases del Derecho Penal. Montevideo: Julio César Faira Editor, 2003, p. 112.

MORAIS DA ROSA, Alexandre; LOPES, Ana Cristina Brito. Introdução crítica ao ato infracional: princípios e garantias constitucionais. Rio de Janeiro: Lumen Juris, 2011.

MORAIS DA ROSA, Alexandre. Decisão penal: a bricolagem de significantes. Rio de Janeiro: Lúmen Juris, 2006.

MUÑOZ CONDE, Francisco. Direito penal e controle social. Rio de Janeiro: Forense, 2005.

. Função motivadora da norma penal e marginalização. Revista Justitia. São Paulo, v.48, n.135, p.32-38, jul./set., 1986.

Edmund Mezger e o Direito Penal de seu tempo: estudos sobre o Direito Penal no nacional-socialismo. 4. ed. Tradução de Paulo César Busato. Rio de Janeiro: Lumen Juris, 2005. p. 66-68

NIETZSCHE, Friedrich. Aurora: reflexões sobre os preconceitos morais. São Paulo: Companhia das Letras, 2004.

PRADO, Luiz Regis. Curso de Direito Penal Brasileiro: parte geral. 10.ed.rev.atual. ampl. São Paulo: Editora Revista dos Tribunais, 2010. v.1

RAMIDOFF, Mário Luiz. Lições de Direito da criança e do adolescente: ato infracional e medidas socioeducativas. Curitiba: Juruá, 2011.

ROXIN, Claus. Estudos de Direito Penal. 2. ed. Tradução de Luís Greco. Rio de Janeiro: Renovar, 2008.

Política criminal e sistema jurídico-penal. Tradução de Luís Greco. Rio de Janeiro: Renovar, 2002.

SANTOS, Juarez Cirino. A criminologia radical. 2.ed. Curitiba: ICPC; Lumen Juris, 2006.

RUSCHE, Georg; KIRCHHEIMER, Otto. Punição e estrutura social. Tradução de Gizlene Neder. Rio de Janeiro: Freitas Bastos/Instituto Carioca de Criminologia, 1999.

WACQUANT, Loïc. As prisões da miséria.Tradução de André Telles. Rio de Janeiro: Jorge Zahar Editor, 2001. 
Punir os pobres: a nova gestão da miséria nos Estados Unidos [A onda punitiva]. Tradução de Sérgio Lamarão. Rio de Janeiro: Revan, 2007.

WINFRIED, Hassemer. Darf es Strafteten geben, die ein strafrechtliches Rechtsgut nicht in Mitleidenschaft ziehen? In: HEFENDEHL, Roland; HIRSH, Andrew von; WOHLERS, Wolfgang, (Hrsg.). Die Rechtsgutstheorie: legitimationsbasis des Strafrechts oder dogmatisches Glasperlenspiel? Baden-Baden: Nomos, 2003. p.64.

ZAFFARONI, Eugênio Raúl. Em busca das penas perdidas: a perda de legitimidade do sistema penal. Tradução de Vania
Romano Pedrosa e Almir Lopez da Conceição. Rio de Janeiro: Revan, 2012.

O inimigo no Direito Penal. Tradução de Sérgio Lamarão. Rio de Janeiro: Revan, 2007.

ZAFFARONI, Eugênio Raúl; PIERANGELI, José Henrique. Manual de Direito Penal Brasileiro: parte geral. 6. ed. rev. atual. São Paulo: Editora Revista dos Tribunais, 2006.

Recebido em dezembro de 2013. Aceito em março de 2014. 